\title{
Systemic Acquired Resistance (SAR) in integrated plant protection
}

\section{Systemiczna odporność nabyta (Systemic Acquired Resistance - SAR) w integrowanej ochronie roślin}

\author{
Henryk Pospieszny*
}

\begin{abstract}
Summary
Disease control is largely based on the use of different chemical compounds toxic to pathogens. However, the hazardous effect of these chemicals on the environment and human health strongly forces to seek harmless means of disease control. During the evolutionary process, plants have developed many different defence mechanisms against pathogens. Systemic Acquired Resistance (SAR) is one of the most promising defence mechanisms which is induced not only by pathogens but also by molecules released during plant-pathogen interaction. Exogenous application of SAR inducers is an interesting and safe for the environment a means of plant protection, because they do not act directly on pathogens (and other microorganisms) but only by a plant metabolism. The SAR acts against broad-spectrum of pathogens and can be quite long time lasting but it is rarely complete. The SAR is a plant response and that can be affected by numerous factors for instance environment, plant and pathogen genotypes, plant health condition, and means of the inductor application. The use of the resistance inducers is still limited in the practice. Our current knowledge about it comes mainly from experimental trials and there is a need to develop more wide scale field experiments. Presently, the following benefits of using resistance inducers can be expected: (1) reduction of damage of pathogens, (2) reduction of application of pesticides that present hazards to environmental human, (3) inductors can be alternative to genetically modified plants, (4) they can be applied together with fungicide.
\end{abstract}

Key words: disease control; induced resistance; systemic acquired resistance; localized acquired resistance; factors affecting SAR induction

\section{Streszczenie}

Ochrona roślin przed patogenami opiera się głównie na stosowaniu pestycydów, które są bezpośrednio toksyczne dla patogenów. Chemikalia te są szkodliwe dla środowiska i człowieka, co zmusza do poszukiwania bardziej bezpiecznych sposobów ochrony roślin. Rośliny w trakcie ewolucji nabyły mechanizmy obronne, z których bardzo obiecująca jest systemiczna odporność nabyta (Systemic Acquired Resistance - SAR). SAR jest indukowana przez patogeny, ale także przez inne czynniki powodujące wytwarzanie molekuł sygnałowych w roślinie. Systemiczna odporność nabyta chroni rośliny przed zakażeniem przez szerokie spektrum patogenów i jest stosunkowo trwała, ale rzadko całkowita. SAR jest reakcją rośliny i na jej wystąpienie mają wpływ liczne czynniki, takie jak: warunki środowiskowe, genotypy rośliny i patogenu, kondycja rośliny, sposób aplikacji induktora oraz inne. Stosowanie induktorów w praktyce jest wciąż ograniczone. Wiedza o zjawisku pochodzi głównie z badań eksperymentalnych i istnieje potrzeba rozwinięcia na szeroką skalę badań w warunkach polowych. Obecnie, ze stosowania induktorów SAR można oczekiwać następujących korzyści: (1) ograniczanie szkodliwości patogenów, (2) ograniczanie stosowania szkodliwych dla człowieka i środowiska pestycydów, (3) są alternatywą dla roślin genetycznie modyfikowanych, (4) można je stosować łącznie z fungicydami.

Słowa kluczowe: ograniczanie chorób; odporność indukowana; systemiczna odporność nabyta; induktory odporności; czynniki wpływające na indukcję SAR

\footnotetext{
Instytut Ochrony Roślin - Państwowy Instytut Badawczy

Zakład Wirusologii i Bakteriologii

Władysława Węgorka 20, 60-318 Poznań

*corresponding author: H.Pospieszny@iorpib.poznan.pl
} 


\section{Wstęp / Introduction}

Rośliny, podobnie jak inne organizmy są nieustannie narażone na działanie różnych czynników chorobotwórczych. Statyczny charakter roślin nie pozwala im na przemieszczanie się w bardziej korzystne dla siebie warunki oraz brak aktywnego, układowego systemu immunologicznego (obronnego) podobnego do ludzkiego i zwierzęcego stanowią dla nich szczególne utrudnienie w przeciwstawianiu się czynnikom stresowym, w tym chorobotwórczym. A jednak w naturze infekcja chorobowa roślin jest raczej wyjątkiem niż regułą. Dzieje się tak dlatego, że rośliny w czasie ewolucji nabyły szereg różnych, niekiedy bardzo wyrafinowanych mechanizmów obronnych przeciwko czynnikom chorobotwórczym, a szerzej przeciwko stresom biotycznym. Przy braku tych mechanizmów obronnych nawet minimalna ilość patogenu byłaby zabójcza dla roślin.

Rośliny są trwale (genetycznie) wyposażone w odporność indukowaną przez patogeny, która jest zwykle w stanie większego lub mniejszego wyciszenia i uruchamia się w czasie ataku czynnika chorobotwórczego lub zewnętrznie zastosowanego induktora odporności. Stosowanie pestycydów w ochronie roślin przed patogenami jest często szkodliwe dla człowieka i środowiska. Istotą integrowanej ochrony roślin jest ograniczenie zużycia klasycznych środków ochrony, w czym znaczący udział może mieć odporność indukowana.

Niniejsza praca koncentruje się głównie na uwarunkowaniach pozwalających na efektywne włączanie odporności indukowanej, szczególnie systemicznej odporności nabytej (SAR), do programów integrowanej ochrony roślin.

\section{Typy odporności indukowanej / Types of induced resistance}

\section{Lokalna odporność nabyta (Localized Acquired Resistance - LAR)}

LAR występuje jedynie w miejscu ataku patogenu oraz w sąsiednich komórkach i nie rozprzestrzenia się systemicznie, czyli do części roślin nieporażonych przez patogeny lub traktowanych induktorami odporności (Kombrink i Schmelzer 2001).

\section{Systemiczna odporność nabyta (Systemic Acquired Resistance - SAR)}

Gdy z miejsc inwazji patogenów lub części roślin traktowanych induktorami przemieszczają się substancje sygnalne, które wzbudzają odporność w częściach roślin oddalonych od porażonych przez patogeny lub traktowanych induktorami, występuje wtedy zjawisko nazywane jako systemiczna odporność nabyta.

SAR jest indukowana przez patogeny oraz substancje naturalne $\mathrm{i}$ syntetyczne imitujące interakcję patogenroślina. Indukcja SAR przebiega szlakiem sygnalnym kwasu salicylowego (SA - Salicylic Acid) (Spoel i Dong 2012) i towarzyszy temu zjawisku synteza wielu różnych innych substancji sygnalnych oraz białek związanych z patogenezą (białka PR - PR Proteins - Pathogenis Related Proteins) (Van Loon 1985). Istotną zaletą SAR jest jej działanie przeciwko szerokiemu zakresowi patogenów.

\section{Systemiczna odporność indukowana (Induced Systemic Resistance - ISR)}

ISR indukowana jest przez niepatogeniczne bakterie i grzyby rizosfery stymulujące wzrost roślin (PGPR - Plant Growth Promoting Rhizobacteria), z których najlepiej rozpoznane są niektóre gatunki z rodzajów Pseudomonas i Bacillus (Van Loon i wsp. 1998; Lugtenberg i Kamilowa 2009), a także przez grzyby mikoryzowe (Cordier i wsp. 1998; Pozo i Azcón-Aguilar 2007). Systemiczna odporność indukowana przebiega szlakiem sygnalnym, w którym podstawową rolę odgrywają kwas jasmonowy (JA Jasmonic Acid) i etylen. SAR i ISR są fenotypowo podobne czyli są efektywne przeciwko grzybom, bakteriom i wirusom. Jednak ISR w przeciwieństwie do SAR jest indukowana na bardziej ograniczonym zakresie gatunków roślin, co jest efektem specyficzności niektórych szczepów bakterii PGPR względem niektórych gatunków roślin (Van Wees i wsp. 2008). Także liczba dostępnych induktorów ISR jest znacznie mniejsza w porównaniu z SAR.

\section{Systemiczna odporność indukowana - typu kwasu B-aminobutyrowego (BABA - B-Aminobutiric Acid)}

Indukcja odporności przez BABA nie przebiega ani szlakiem sygnalnym kwasu salicylowego, jak w przypadku SAR, ani szlakiem sygnalnym kwasu jasmonowego i etylenu, jak u ISR. Odporność ta występuje przy ograniczonym zakresie gatunków roślin i przeciwko ograniczonemu zakresowi patogenów, głównie grzybowych (Hong i wsp. 1999).

\section{Induktory odporności indukowanej / Inducers of induced resistance}

Spośród wyżej wymienionych typów odporności indukowanej, ze względów praktycznych największe nadzieje $\mathrm{w}$ wykorzystaniu $\mathrm{w}$ praktyce wiąże się $\mathrm{z}$ systemiczną odpornością nabytą (SAR). Szczególnie istotna jest dostępność do różnego typu induktorów SAR. Induktorami (elicitorami) SAR są molekuły grzybów, bakterii i wirusów, najczęściej białka oraz złożone polisacharydy, a także niekiedy proste substancje chemiczne biorące udział w procesie indukcji SAR.

W roku 1933 zaobserwowano zjawisko (Chester 1933), które dopiero w roku 1961 dokładnie przebadano i nazwano systemiczną odpornością nabytą (SAR) (Ross 1961). Zjawisko to początkowo przypisywano głównie patogenom nekrotyzującym tkankę roślinną. Stosowanie patogenów jako induktorów SAR byłoby z wielu powodów wyjątkowo uciążliwe. Intensywne badania nad SAR rozpoczęte $\mathrm{z}$ początkiem lat 80 . ubiegłego stulecia pozwoliły ustalić różne typy odporności indukowanej, poznać niektóre elementy mechanizmów indukcji odporności oraz wykazać, że stymulatorem SAR może być nie tylko charakterystyczna molekuła patogenu, ale także 
niektóre substancje syntetyzowane przez rośliny w procesie indukcji odporności (White 1979; Kuc 1982; Van Loon i Antoniw 1982). Dzięki rozpoznaniu tych substancji, można je izolować, modyfikować, a nawet syntetyzować w sposób powtarzalny i stosować zewnętrznie jako induktory odporności poprzez naśladowanie (imitację) interakcji patogen-gospodarz. Dzięki temu istnieje możliwość wzbudzania w roślinach reakcji odpornościowych w sposób wyprzedzający atak patogenu.

W latach 90. ubiegłego stulecia wprowadzono do praktyki chemiczne oraz naturalne induktory SAR. Najwyższą potencjalną efektywność wykazywała substancja benzo(1,2,3)tiodiazol (BTH - benzo(1,2,3)thiadiazole) (Kunz i wsp. 1997) i pochodne S-methyl benzo(1,2,3) thiadiazole-7-carbothiate (ASM - acibenzolar-S-metyl) (Cools i Ishii 2002). Związek BTH jest substancją czynną między innymi preparatu Bion. Substancja ta jest funkcjonalną i strukturalną pochodną kwasu salicylowego. BTH jest jednym z najlepszych induktorów SAR, ale nie przyjął się $\mathrm{W}$ praktyce, głównie dlatego, że strona aplikująca nie była odpowiednio przygotowana na przyjęcie innowacyjnego produktu, niebędącego kolejnym klasycznym środkiem ochrony roślin. Induktor BTH należy stosować profilaktycznie oraz rygorystycznie przestrzegać zalecanej dawki. Przekroczenie dawki BTH, w warunkach szklarniowych często skutkowało fitotoksycznością i zniechęcało do stosowania induktora. Historycznie rzecz biorąc pierwszym induktorem odporności była substancja probenazol, którą zarejestrowano $\mathrm{w}$ roku 1975, w Japonii, do zwalczania tylko chorób grzybowych ryżu (Iwata 2001). Inne chemiczne i niebiologiczne induktory odporności to: kwas 2,6-dwuchloroisonikotynowy (INA - 2,6-dichloroisonicotinic acid) i jego pochodne (Qian i wsp. 2006), kwas ß-aminobutyrowy (BABA) (Hong i wsp. 1999), sacharin (metabolit probenazolu) (Uchiyama i wsp. 1973), fosforyny (Hardy i wsp. 2001), silikon (Kvedaras i wsp. 2010) i inne. Do najważniejszych biologicznych stymulatorów odporności systemicznej zalicza się: grzyby mikoryzowe, bakterie i grzyby korzeniowe stymulujące wzrost roślin (PGPR) (Cordier i wsp. 1998; Van Loon i wsp. 1998; Ryu i wsp. 2006) oraz ekstrakty z alg, takie jak laminaryna (ß-glukan) i ß-1,3 fukan (Cluzet i wsp. 2004), a także chitozan (produkt deacetylacji chityny) (Pospieszny i wsp. 1991; Pospieszny 1997; Xing i wsp. 2015) oraz inne wyciągi $z$ roślin i mikroorganizmów.

\section{Zalety SAR i jej induktorów / Merits of SAR and their inducers}

Biorąc pod uwagę zarówno efektywność, jak i możliwość zastosowania w praktyce, w szerokim zakresie, największe nadzieje wiąże się z systemiczną odpornością nabytą (SAR). Zarówno SAR, jak i jej induktory cechują się wieloma korzystnymi właściwości.

(1) Odporność indukowana typu SAR jest aktywna przeciwko najszerszemu zakresowi patogenów, często jednocześnie przeciwko grzybowym, bakteryjnym i wirusowym. Szczególnie przeciwwirusowa aktywność SAR istotnie poszerza możliwości ograniczania występowania wiroz. Trzeba jednak podkreślić, że w przypadku wirusów wymagana jest szczególnie wysoka efektywność induktorów $\mathrm{w}$ indukcji odporności w porównaniu $\mathrm{z}$ patogenami grzybowymi (Lewandowski i wsp. 2014; Śmiglak i wsp. 2014).

(2) Odporność indukowana jako zjawisko naturalne oraz $\mathrm{w}$ większości jej induktory są bezpieczne dla środowiska, gdyż nie działają bezpośrednio na mikroorganizmy i nie naruszają jego równowagi biologicznej (Poppy i Wilkinson 2005).

(3) W przeciwieństwie do klasycznych środków ochrony roślin, patogeny nie uodporniają się ani na SAR, bo jest to zjawisko bardzo złożone, ani na jej induktory, bo nie wchodzą one $\mathrm{w}$ bezpośrednią interakcję $\mathrm{z}$ patogenem.

(4) SAR wykazuje stosunkowo dużą trwałość, a nawet może przechodzić z pokolenia na pokolenie (Luna i wsp. 2012).

(5) W integrowanej ochronie roślin nie tylko jest możliwe, a wręcz pożądane łączne stosowanie środków ochrony roślin $\mathrm{z}$ induktorami SAR, gdyż może to być szansą na uzyskanie efektu synergistycznego i prowadzić do znacznego ograniczenia liczby zabiegów chemicznych (Walters i wsp. 2010; Ji i wsp. 2011). W tym przypadku, łączne stosowanie należy rozumieć jako ograniczanie występowania choroby grzybowej przy zastosowaniu obu sposobów, ale początkowo niejednocześnie, gdyż induktory są stosowane profilaktycznie, a fungicydy dopiero wtedy, gdy induktory SAR tracą skuteczność. Łączne stosowanie induktorów SAR $\mathrm{z}$ insektycydami może bardzo skutecznie ochronić rośliny przed wirusami przenoszonymi przez mszyce. Mszyca potraktowana insektycydem zanim zostanie zwalczona wykonuje szereg nerwowych nakłuć, w trakcie których może wprowadzić wirusa do rośliny, wówczas roślina wyposażona w SAR może obronić się przed infekcją wirusową.

(6) SAR może stanowić alternatywę dla roślin genetycznie modyfikowanych (GM - Genetically Modified) (Kappers i wsp. 2005) w sytuacji braku ich akceptacji przez społeczeństwo. Obecnie w Polsce i Europie problemem jest masowe występowanie wirusa mozaiki pepino na pomidorach szklarniowych. W sytuacji, kiedy całkowicie zawodzi wielokierunkowa profilaktyka, producenci pomidora stosują działanie ostateczne, jakim jest np. indukowanie odporności krzyżowej, inaczej immunizacja roślin łagodnymi izolatami wirusa, aby uchronić je przed izolatami agresywnymi. Należy w tym miejscu wspomnieć o paradoksie jakim jest fakt, że często nie akceptuje się jednego genu i jednego białka wirusowego w roślinie pomidora genetycznie modyfikowanego, ale akceptuje się (prawdopodobnie nieświadomie) co najmniej pięć genów i co najmniej 5 białek wirusowych w przypadku świadomej immunizacji roślin pomidora wirusem ochronnym (cross-protection) lub wystąpienia infekcji wirusowej. Rośliny genetycznie modyfiko- 
wane nie zawsze muszą wprost negatywnie wpływać na człowieka, ale mogą powodować negatywne skutki uboczne dla środowiska, wynikające ze stosowanej technologii i obecności roślin GM w tymże środowisku. Takie obiekcje i wątpliwości nie dotyczą zjawiska SAR. Można dodatkowo wskazać na przewagę SAR nad roślinami genetycznie modyfikowanymi oraz immunizacją roślin przeciwko wirusom, których skuteczność jest skierowana jedynie przeciwko konkretnemu szczepowi w obrębie danego gatunku wirusa, a zjawisko SAR może być efektywne jednocześnie przeciwko różnym gatunkom wirusów, a także innym patogenom.

(7) Nie bez znaczenia jest fakt, że do aplikacji induktorów odporności stosuje się takie same techniki, jak w klasycznej ochronie roślin przed patogenami i nie generuje to dodatkowych utrudnień i kosztów (Thakur i Sohal 2013).

(8) Z uwarunkowań technicznych bardzo ważny jest fakt, że induktory SAR są w większości produkowane jako preparaty o zunifikowanych i stabilnych właściwościach fizykochemicznych, co pozwala na opracowywanie powtarzalnych warunków ich stosowania (Henry i wsp. 2012).

Pewnym utrudnieniem może być odmienny termin stosowania induktorów SAR w porównaniu z klasycznymi pestycydami. Induktory nie działają na patogeny wprost, a jedynie poprzez metabolizm rośliny i dlatego stosuje się je profilaktycznie, przed wystąpieniem patogenu, aby rośliny miały odpowiednio długi czas do aktywacji swoich mechanizmów obronnych. Termin traktowania roślin induktorami należy ustalić wyprzedzająco w stosunku do pojawienia się patogenów, korzystając $\mathrm{z}$ dotychczasowego doświadczenia i wiedzy o ich występowaniu. Induktory SAR nie działają kuratywnie i spóźnione traktowanie roślin induktorami będzie skutkować niską ich efektywnością.

Innym efektem profilaktycznego stosowania induktorów SAR jest brak gwarancji, że patogen wystąpi w ogóle i wtedy wysiłek roślin okaże się nieproduktywny (Van Hulten i wsp. 2006). W warunkach polowych zjawisko SAR praktycznie nigdy nie chroni roślin całkowicie przed patogenami, gdyż efektywność odporności indukowanej jest wypadkową wielu różnych czynników, przedstawionych poniżej.

\section{Czynniki wpływające na wystąpienie SAR I Factors affecting the performance of SAR}

\section{Gatunek i genotyp gospodarza}

Potencjalnie SAR można indukować na wielu różnych gatunkach roślin przy czym ich wrażliwość na różne induktory może być istotnie różna (Oxley i Walters 2012). Jeżeli już na poziomie badań gatunek wykazuje słabą wrażliwość na dany induktor, można być pewnym, że nie jest on przydatny do indukcji odporności na niektórych gatunkach roślin w praktyce.

Generalnie uważa się, że zjawisko odporności indukowanej lepiej występuje na roślinach dwuliściennych niż jednoliściennych. Sądzi się jednak, że w dużej mierze ma to związek ze stosunkowo znacząco ograniczonymi badaniami nad aplikacją induktorów SAR na roślinach jednoliściennych $\mathrm{w}$ porównaniu $\mathrm{z}$ dwuliściennymi. Rośliny jednoliścienne są uprawiane tylko w warunkach polowych, a ich anatomia stwarza pewne utrudnienia w aplikacji induktorów.

Wpływ odmiany na efektywność SAR może być niekiedy znaczący. Wykazano, że odmiany jęczmienia w dużym zakresie różniły się wrażliwością na elicitory indukujące SAR przeciwko mączniakowi, a w niektórych odmianach nawet $\mathrm{w}$ ogóle nie udało się wzbudzić odporności (Walters i wsp. 2010). Podobny efekt obserwowano w przypadku pomidora i zarazy ziemniaka (Phytophtora infestans) (Sharma i wsp. 2010). W hodowli roślin pojawiła się tendencja do tworzenia odmian genetycznie przydatnych do stosowania induktorów SAR.

\section{Patogeny}

SAR jest skierowana przeciwko stosunkowo szerokiemu i zróżnicowanemu zakresowi patogenów (grzyby, bakterie i wirusy), jednak w nierównym stopniu, a dodatkowo zróżnicowanie genetyczne wewnątrz gatunku patogenu także może mieć znaczący wpływ na indukcję SAR (Sharma i wsp. 2012).

\section{Koszty indukcji SAR}

Indukcja odporności jest kosztowna i wymaga od rośliny nakładu energii i metabolitów, takich samych jakie one używają do swojego wzrostu i rozwoju, i zwykle roślina posiada wystarczającą ich ilość do pokrycia potrzeb związanych z rozwojem i obroną (Murray i Walters 1992). Możliwości te są zapisane w genotypie rośliny. Często występują także dodatkowe koszty związane ze środowiskiem, szczególnie w warunkach niedostatku wody lub składników pokarmowych i wtedy może dojść do naruszenia równowagi $\mathrm{w}$ gospodarce metabolicznej roślin polegającej na przesunięciu wydatków energii i surowców $\mathrm{Z}$ rozwoju do indukcji odporności (allocation costs), w efekcie końcowym przejawia się to redukcją plonu, zawartości białek, a nawet fitotoksycznością (Heil i Baldwin 2002).

Problemy z kosztami kondycyjnymi (fitness costs) zależą od wielu czynników, nie zawsze do końca rozpoznanych, między innymi takich jak: natura chemiczna induktora, dawki, gatunek i odmiana roślin, sposób uprawy, układ roślina-patogen, kondycja uprawy, itd. Induktory SAR stosuje się profilaktycznie i w przypadku nie wystąpienia patogenu roślina ponosi zbędne straty w wydatkowaniu energii i surowców, co w niekorzystnych warunkach środowiskowych może przejawić się obniżka plonu (Heil i wsp. 2000). Problem ten można częściowo rozwiązać przez odpowiedni dobór induktora, który wzbudza (priming) mechanizmy obronne, ale nie indukuje pełnej odporności i wtedy nakłady energetyczne rośliny są niższe (Van Hulten i wsp. 2006). Wzbudzenie - jest to stadium przedtranskrypcyjne genów kodujących metabolity towarzyszące indukcji odporności, powodujące szybszą oraz silniejszą reakcję roślin w przypadku ataku patogenu. Zjawisko to wciąż nie jest w pełni rozpoznane, 
ale ekologicznie korzystne i o dużym potencjale aplikacyjnym $\mathrm{w}$ ochronie roślin przed patogenami.

\section{Sposób i częstotliwość aplikacji oraz dawka induktora}

W warunkach szklarniowych, w przeciwieństwie do polowych, rośliny w mniejszym stopniu są narażone na stres wodny oraz pokarmowy i efektywniej przebiega proces indukcji odporności. Można także łatwiej i dokładniej technicznie przeprowadzić traktowanie roślin induktorami $\mathrm{w}$ tych warunkach niż $\mathrm{w}$ polu, dotyczy to zarówno sposobu pokrycia roślin roztworem induktora, jak i sposobu jego podania. Dłuższy kontakt induktora z rośliną daje większą szansę na wyższą efektywność indukcji SAR. W szklarniach jest większa możliwość stworzenia warunków do wydłużenia okresu odparowywania induktorów z powierzchni opryskiwanych liści. Także w szklarni istnieją zdecydowanie łatwiejsze niż w polu możliwości aplikacji induktorów do korzeni. Induktor jednorazowo podany przez podlewanie indukuje odporność na wysokim poziomie w młodych, kolejno rozwijających się liściach przez co najmniej miesiąc (Śmiglak i wsp. 2014). Przy opryskiwaniu roślin induktorami, systemiczna odporność indukowana występuje głównie na liściach traktowanych i zabieg należy powtarzać w 7-10-dniowych odstępach czasu. Częstotliwość aplikacji induktora jest zagadnieniem, które ma istotne znaczenie dla praktyki nie tylko ze względu na efektywność ochrony, ale także jej koszty. Przykładowo, większą efektywność ochrony pomidora w polu osiągano przy zabiegach induktorem SAR w cotygodniowych niż codwutygodniowych odstępach czasu (Huang i wsp. 2012). Podawanie induktora do korzeni roślin wraz $\mathrm{z}$ nawadnianiem lub dokarmianiem można przeprowadzać rzadziej. W przypadku niektórych induktorów należy rygorystycznie przestrzegać zalecanych dawek, szczególnie na młodych, intensywnie rozwijających się stadiach rozwojowych roślin ze względu na możliwość alokacji kosztów (allocation costs), co może przejawiać się ograniczeniem wzrostu roślin.

\section{Wpływ czynników abiotycznych środowiska na indukcję SAR}

Jak wspomniano wyżej, indukcja systemicznej odporności nabytej jest kosztowna i wymaga nakładu energii i metabolitów, co może stawiać przed rośliną wybór: rozwój (wzrost) czy obrona (Herms i Mattson 1992). Jest logiczne, że niedostatek metabolitów lub substancji będzie miał wpływ na indukcję SAR. Założenie to poparto wynikami badań, wykazując, że w roślinach przy ograniczonym dostępie do azotu wystąpiło silniejsze przemieszczenie kosztów (allocation cost) niż w przypadku dostatku azotu (Heil i wsp. 2000). Przesunięcie nakładów energii i surowców wystąpiło nie tylko przy niedoborze nawozów azotowych, ale także w stresie wodnym oraz przy współzawodnictwie $\mathrm{z}$ innymi roślinami (Dietrich i wsp. 2004). W warunkach stresowych, przy słabszej kondycji roślina nie może sprostać dodatkowemu obciążeniu, jakim jest dla niej uruchamianie systemu obronnego. W korzystnych warunkach roślina jest zdolna sprostać wymogom zarówno prawidłowego rozwoju, jak i działaniom obronnym (Murray i Walters 1992). W warunkach polowych na rośliny może oddziaływać negatywnie jednocześnie i w różnym nasileniu kilka różnych czynników, czasami trudnych do przewidzenia lub zweryfikowania.

\section{Wpływ czynników biotycznych środowiska na indukcję SAR}

W warunkach polowych, w niektórych roślinach mniej lub bardziej wyraźnie stwierdzano występowanie markerów charakterystycznych tylko dla odporności indukowanej (Hammerschmidt 2007). Istnieje wiele możliwości indukowania różnego typu odporności przez różne czynniki i zjawiska biotyczne środowiska naturalnego, takie jak: mikoryza (Pozo i Azcón-Aguilar 2007), grzybowe i bakteryjne endofity (Waller i wsp. 2005), patogeny, szkodniki (Bostock 2005) oraz nicienie (w odpowiednio wysokim nasileniu) (Kosaka i wsp. 2001) i inne. Pomiędzy różnymi typami odporności indukowanej może dochodzić do konfliktu (negative crosstalk). Nasuwa się pytanie o wpływ odporności indukowanej w sposób naturalny, niekontrolowany na odporność indukowaną przez induktory celowo stosowane. Niekiedy, w takich okolicznościach obserwowano zmienny efekt stosowania induktorów SAR, co zostało potwierdzone eksperymentalnie (Walters i wsp. 2010). Generalnie, zasięg tego zjawiska jest ograniczony.

\section{Uwagi końcowe / Final remarks}

Uważa się, że przy obecnych tendencjach do silnego ograniczania stosowania chemii w produkcji płodów rolnych, SAR jest ważną alternatywą dla pestycydów, tam gdzie nie można ich stosować lub/i sposobem ograniczenia chemii, tam gdzie ją trzeba stosować.

Powszechne wykorzystanie naturalnych mechanizmów obronnych roślin może zrewolucjonizować ochronę roślin przed patogenami, a co najmniej istotnie wesprzeć integrowaną ochronę roślin. O tym zadecydują dwa fakty: (1) świadomość producentów produktów rolnych oraz (2) zunifikowanie technologii indukcji SAR. Wbrew pozorom to pierwsze zagadnienie jest trudniejsze. Rolnicy wciąż co najmniej z rezerwą odnoszą się do tego typu technologii, nie dorównującej efektywnością klasycznym pestycydom. Zaakceptują każdą nową propozycję byle była totalna, a systemiczna odporność nabyta im tego nie gwarantuje. Należy oczekiwać, że obowiązkowe wprowadzanie zasad rolnictwa integrowanego przez Unię Europejską będzie sprzyjało rozwojowi różnych biologicznych metod ochrony roślin. Szerszej akceptacji odporności indukowanej przez praktykę powinna służyć zmiana w myśleniu o odporności indukowanej i jej induktorach. Nie należy oczekiwać rozwiązania problemów patogenów w integrowanym rolnictwie przez totalne ich zniszczenie $\mathrm{z}$ użyciem pestycydów, ale ograniczenia ich występowania do poziomu nieszkodliwego, co w wielu sytuacjach można uzyskać właśnie przez stosowanie induktorów SAR. Zjawisko SAR może bardzo poważnie przyczynić się także do ograniczenia zużycia środków ochrony roślin opartych 
na substancjach chemicznych, często szkodliwych dla szeroko pojętego środowiska.

SAR jest zjawiskiem złożonym, a jej zastosowanie w praktyce wymaga kompleksowych działań, co nadaje całości charakter wręcz technologii. Rozpoznanie zjawiska odporności indukowanej na poziomie molekularnym pozwoliło zidentyfikować substancje biorące $\mathrm{w}$ nim udział i wykazać, że niektóre $\mathrm{z}$ nich same posiadają zdolność indukowania SAR. Są to induktory naturalne, które można syntetyzować $\mathrm{w}$ potrzebnych ilościach i modyfikować celem zwiększenia ich efektywności. Coraz większa jest też wiedza o czynnikach wpływających na efektywność indukcji SAR, co pozwala między innymi na prowadzenie hodowli roślin ukierunkowanej na tworzenie odmian specjalnie przeznaczonych do wykorzystania SAR w ochronie roślin. Cechują się one dużą wrażliwością na indukcje SAR oraz zdolnością do pokrywania kosztów indukcji odporności w większym stopniu niż obecnie dostępne odmiany. Są także prowadzone badania nad nowymi modyfikacjami znanych induktorów celem podniesienia ich efektywności oraz tworzeniem mieszanin induktorów nie tylko niewykluczających się, ale działających synergistycznie (Lewandowski i wsp. 2014).

Jest mało prawdopodobne, aby w najbliższym czasie została opracowana technologia bardziej bezpieczna i przyjazna dla środowiska niż zjawisko SAR. Jest ono zaproponowane i sprawdzone przez naturę.

Praca została opublikowana w ramach badań prowadzonych w projekcie badawczym OPUS 9 pt. „Systemiczna odporność nabyta (Systemic Acquired Resistance, SAR) roślin przeciwko wirusom: nowe induktory oraz biologiczna i molekularna charakterystyka mechanizmów ich działania" nr 2015/17/B/NZ9/01676, finansowanych przez Narodowe Centrum Nauki.

\section{Literatura / References}

Bostock R.M. 2005. Signal crosstalk and induced resistance: straddling the line between cost and benefit. Annual Review of Phytopathology 43: 545-580.

Chester K.S. 1933. The problem of acquired physiological immunity in plants. The Quarterly Review of Biology 8 (2): $275-324$.

Cluzet S., Torregrosa C., Jacquet C., Lafitte C., Fournier J., Mercier L., Salamagne S., Briand X., Esquerré-Tugayé M.T., Dumas B. 2004. Gene expression profiling and protection of Medicago truncatula against a fungal infection in response to an elicitor from green algae Ulva ssp. Plant Cell and Environment 27 (7): 917-928.

Cools H.J., Ishii H. 2002. Pre-treatment of cucumber plants with acibenzolar-S-methyl systemically primes phenylalanine ammonia lyase gene $(P A L I)$ for enhanced expression upon attack with the a pathogenic fungus. Physiological and Molecular Plant Pathology 61:273-280.

Cordier C., Pozo M.J., Barea J.M., Gianinazzi S., Gianinazzi-Pearson V. 1998. Cell defence responses associated with localized and systemic resistance Phytophtora parasitica induced by in tomato an arbuscular mycorrhizal fungus. Molecular Plant-Microbe Interactions 11 (10): 1017-1028.

Dietrich R., Ploss K., Heil M. 2004. Constitutive and induced resistance to pathogens in Arabidopsis thaliana depends on nitrogen supply. Plant, Cell and Environment 27 (7): 896-906.

Hammerschmidt R. 2007. Introduction: definitions and some history. Chapter 1. p. 1-8. In: "Induced Resistance for Plant Defence: a Sustainable Approch to Crop Protection" (D. Walters, A. Newton, G. Lyon, eds.). Blackwell Publishing, Oxford, 258 pp.

Hardy G.E.St.J., Barrett S., Shearer B.L. 2001. The future of phosphate as a fungicide to control the soilborne plant pathogen Phytophtora cinnamomi in natural ecosystems. Australasian Plant Pathology 30: 133-139.

Heil M., Baldwin I.T. 2002. Fitness costs of induced resistance: emerging experimental support for a slippery concept. Trends in Plant Science 7 (2): 61-67.

Heil M., Hilpert A., Kaiser W., Linsenmair K.E. 2000. Reduced growth and seed set following chemical induction of pathogen defence: does systemic acquired resistance (SAR) incur allocation costs? Journal of Ecology 88 (4): 645-654.

Henry G., Thonart P., Ongena M. 2012. PAMPs, MAMPs, DAMPs and others: an update on the diversity of plant immunity elicitors. Biotechnology, Agronomy and Society and Environment 16 (2): 257-268.

Herms D.A., Mattson W.J. 1992. The dilemma of plants: to grow or defend. The Quarterly Review of Biology 67 (3): $283-335$.

Hong J.K., Hwang B.K., Kim C.H. 1999. Induction of local and systemic resistance to Colletotrichum coccodes in pepper plants by DL-beta-amino-n-butyric acid. Journal of Phytopathology 147 (4): 193-198.

Huang Ch.-H., Vallad G.E., Zhang S., Wen A., Balogh B., Figueiredo J.F.L., Behlau F., Jones J.B., Momol M.T., Olson S.M. 2012. Effect of application frequency and reduced rates of acibenzolar-S-methyl on the field efficacy of induced resistance against bacterial spot on tomato. Plant Diseases 96 (2): 221-227.

Iwata M. 2001. Probenazole - a plant defence activator. Pesticide Outlook 12 (1): 28-31.

Ji P., Yin J., Kone D. 2011. Application of acibenzolar-S-methyl and standard fungicides for control of Phytophthora blight on squash. Crop Protection 30 (12): 1601-1605.

Kappers I.F., Aharoni A., van Herpen T.W., Luckerhoff L.L., Dicke M., Bouwmeester H.J. 2005. Genetic engineering of terpenoid metabolism attracts bodyguards to Arabidopsis. Science 309 (5743): 2070-2072.

Kombrink E., Schmelzer E. 2001. The hypersensitivity response and its role in local and systemic disease resistance. European Journal of Plant Pathology 107 (1): 69-78.

Kosaka H., Aikawa T., Ogura N., Tabata K., Kiyohara T. 2001. Pine wilt disease caused by the pine wood nematode: the induced resistance of pine trees by the avirulent isolates of nematode. European Journal of Plant Pathology 107: 667-675.

Kuc J. 1982. Induced immunity to plant disease. BioScience 32 (11): 854-860.

Kunz W., Schulter R., Maetzke T. 1997. The chemistry of the benzothiadiazole plant activators. Pesticide Science 50: $275-282$.

Kvedaras O.L., An M., Choi Y.S., Gurr G.M. 2010. Silicon enhances natural enemy attraction and biological through induced plant defences. Bulletin of Entomological Research 100 (3): 367-371. 
Lewandowski P., Kukawka R., Pospieszny H., Smiglak M. 2014. Bifunctional quaternary ammonium salts based on benzo[1,2,3] thiadiazole-7-carboxylate as plant systemic acquired resistance inducers. New Journal of Chemistry 38 (4): 1372-1375.

Lugtenberg B., Kamilowa F. 2009. Plant-growth-promoting rizobacteria. Annual Review of Microbiology 63: 541-556.

Luna E., Bruce T.J.A., Roberts M.R., Flors V., Ton J. 2012. Next-generation systemic acquired resistance. Plant Physiology 158 (2): $844-853$.

Murray D.C., Walters D.R. 1992. Increased photosynthesis and resistance to rust infection in upper, uninfected leaves of rusted broad bean (Vicia faba L.). New Phytologist 120 (2): 235-242.

Oxley S.J.P., Walters D.R. 2012. Control of light leaf spot (Pyrenopeziza brassicae) on winter oilseed rape (Brassica napus) with resistance elicitors. Crop Protection 40: 59-62.

Poppy G.M., Wilkinson M.J. (eds.). 2005. Gene Flow from GM Plants - a Manual for Assessing, Measuring the Risks. Blackwell Publishing, Oxford, UK, 239 pp.

Pospieszny H. 1997. Antiviroid activity of chitosan. Crop Protection 16 (2): 105-106.

Pospieszny H., Chirkov S., Atabekov J. 1991. Induction of antiviral resistance in plants by chitosan. Plant Science 79 (1): $63-68$.

Pozo M.J., Azcón-Aguilar C. 2007. Unraveling mycorrhiza-induced resistance. Current Opinion in Plant Biology 10 (4): $393-398$.

Qian Z.-G., Zhao Z.-J., Xu Y., Qian X., Hong J.-J. 2006. Novel synthetic 2,6-dichloroisonicotinate derivatives as effective elicitors for inducing the biosynthesis of plant secondary metabolites. Applied Microbiology and Biotechnology 71 (2): 164-167.

Ross A.F. 1961. Systemic acquired resistance induced by localized virus infections in plants. Virology 14: 340-358.

Ryu Ch.-M., Kim J., Choi O., Kim S.H., Park Ch.S. 2006. Improvement of biological control capacity of Paenibacillus polymyxa E681 by seed pelleting on sesame. Biological Control 39: 282-289.

Sharma K., Bruns C., Butz A.F., Finckh M.R. 2012. Effects of fertilizers and plant strengtheners on the susceptibility of tomatoes to single and mixed isolates of Phytophtora infestans. European Journal of Plant Pathology 133 (3): 739-751.

Sharma K., Butz A.F., Finckh M.R. 2010. Effects of host and pathogen genotypes on inducibility of resistance in tomato (Solanum lycopersicum) to Phytophtora infestans. Plant Pathology 59 (6): 1062-1071.

Spoel S.H., Dong X. 2012. How do plants achieve immunity? Defence without specialized immune cells. Nature Reviews Immunology $12(2): 89-100$

Śmiglak M., Kukawka R., Lewandowski P., Pospieszny H. 2014. Cationic derivatives of the plant resistance inducer benzo[1,2,3]thiadiazole-7-carbothioic acid S-methyl ester (BTH) as bifunctional ionic liquids. Tetrahedron Letters 55: $3565-3568$.

Thakur M., Sohal B.S. 2013. Role of elicitors in inducing resistance in plants against pathogen infection: a review. International Scholary Research Notices Biochemistry 2013, Article ID 762412, 10 pp.

Uchiyama M., Abe H., Sato R., Shimura M., Watanabe T. 1973. Fate of 3-allyloxy-2,3-benzisothiozole 1,1-dioxide (Oryzemate) in rice plants. Agricultural and Biological Chemistry 37 (4): 735-745.

Van Hulten M., Pelser M., Van Loon L.C., Pieterse C.M.J., Ton J. 2006. Costs and benefits of priming for defense in Arabidopsis. Proceedings of the National Academy of Sciences of the United States of America 103: 5602-5607.

Van Loon L.C. 1985. Pathogenesis - related proteins. Plant Molecular Biology 4 (2): 111-116.

Van Loon L.C., Antoniw J.F. 1982. Comparision of the effects of salicylic acid and ethephon with virus-induced hypersensitivity and acquired resistance in tobacco. Netherlends Journal of Plant Pathology 88 (6): 237-256.

Van Loon L.C., Bakker P.A.H.M., Pieterse C.M.J. 1998. Systemic resistance induced by rhizosphere bacteria. Annual Review of Phytopathology 36: 453-483.

Van Wees S.C., Van der Ent S., Pieterse C.M. 2008. Plant immune responses triggered by beneficial microbes. Current Opinion of Plant Biology 11 (4): 443-448.

Waller F., Achatz B., Baltruschat H., Fodor J., Becker K., Fischer M., Heier T., Hückelhoven R., Neumann C., von Wettstein D., Franken P., Kogel K.-H. 2005. The endophytic fungus Piriformospora indica reprograms barley to salt-stress tolerance, disease resistance, and higher yield. Proceedings of the National Academy Sciences of the United States of America 102 (38): 13386-13391.

Walters D.R., Paterson L., Havis N.D. 2010. Control of foliar diseases of spring barley using resistance elicitors. Journal the Dundee Conference. Crop Protection in Northern Britain 2010. Dundee, UK, 23-24 February 2010: 91-96.

White R.F. 1979. Acetylsalicylic acid (aspirin) induces resistance to tobacco mosaic virus in tobacco. Virology 99 (2): $410-412$.

Xing K., Zhu X., Peng X., Qin S. 2015. Chitosan antimicrobial and eliciting properties for pest control in agriculture: a review. Agronomy for Sustainable Development 35 (2): 569-588. 